\title{
Extract of Cynomorium songaricum ameliorates mitochondrial ultrastructure impairments and dysfunction in two different in vitro models of Alzheimer's disease
}

\author{
Dan Cheng ${ }^{1,2}$, Lei Su' ${ }^{1}$ Xu Wang ${ }^{1}$, Xinjie Li ${ }^{1}$, Lingling $\mathrm{Li}^{1}$, Mengyuan $\mathrm{Hu}^{1}$ and $\mathrm{Yi} \mathrm{Lu}^{1 *}$ (B)
}

\begin{abstract}
Background: Alzheimer's disease (AD) is one of the most common neurodegenerative disorders, but there is still no effective way to stop or slow its progression. Our previous studies demonstrated that extract of Cynomorium songaricum (ECS), a Chinese herbal medicine, had neuroprotective effects in AD models in vivo. However, the pharmacological mechanism of ECS in AD is still unclear.

Methods: To study the mechanisms of action of the effects of ECS on $A D$, we used $A \beta_{25-35-}$ and $\mathrm{H}_{2} \mathrm{O}_{2}$-exposed HT22 cells to mimic specific stages of AD in vitro. The mitochondrial membrane potential (MMP), intracellular ATP, intracellular reactive oxygen species (ROS), and expression levels of mitochondrial dynamics-related proteins in each group were examined. Furthermore, we explored the mechanisms by which ECS reduces the phosphorylation of Drp1 at Ser637 and the changes in the concentrations of intracellular calcium ions in the two models after FK506 intervention.

Results: The results showed that ECS significantly enhanced the MMP $(P<0.05)$, increased intracellular ATP levels $(P<0.05)$ and decreased intracellular ROS levels in the $A \beta$ - and $\mathrm{H}_{2} \mathrm{O}_{2}$-induced cell models $(P<0.05)$. Additionally, ECS regulated the expression levels of mitochondrial dynamics-related proteins by reducing the phosphorylation of Drp1 at Ser637 $(P<0.05)$ and decreasing the expression of Fis1 in the $\mathrm{H}_{2} \mathrm{O}_{2}$-induced models $(P<0.05)$. Further study indicated that ECS reduced the overload of intracellular calcium $(P<0.05)$.
\end{abstract}

Conclusion: Our study results suggest that ECS protects the mitochondrial ultrastructure, ameliorates mitochondrial dysfunction, and maintains mitochondrial dynamics in AD models.

\footnotetext{
* Correspondence: luyi@bucm.edu.cn

'School of Chinese Medicine, Beijing University of Chinese Medicine, Beijing,

China

Full list of author information is available at the end of the article
}

(c) The Author(s). 2021 Open Access This article is licensed under a Creative Commons Attribution 4.0 International License, which permits use, sharing, adaptation, distribution and reproduction in any medium or format, as long as you give appropriate credit to the original author(s) and the source, provide a link to the Creative Commons licence, and indicate if changes were made. The images or other third party material in this article are included in the article's Creative Commons licence, unless indicated otherwise in a credit line to the material. If material is not included in the article's Creative Commons licence and your intended use is not permitted by statutory regulation or exceeds the permitted use, you will need to obtain permission directly from the copyright holder. To view a copy of this licence, visit http://creativecommons.org/licenses/by/4.0/. The Creative Commons Public Domain Dedication waiver (http://creativecommons.org/publicdomain/zero/1.0/) applies to the data made available in this article, unless otherwise stated in a credit line to the data. 


\section{Background}

Alzheimer's disease (AD) is one of the most common neurodegenerative disorders in elderly individuals, and it can cause cognitive dysfunction and interfere with the quality of life of patients. The two pathological characteristics of AD are intracellular neurofibrillary tangles (NFTs) and extracellular senile plaques (SPs) in the hippocampus [1]. NFTs are formed by the misfolding of highly phosphorylated Tau protein, while SPs are formed mainly from the deposition of amyloid-beta (A $\beta$ ) peptides [1]. These misfolded protein aggregates have high neurotoxicity and synaptotoxicity, leading to a cascade of neurodegeneration during the progression of the disease [2].

The deposition of $A \beta$ may result from the continuous interactions of other pathophysiological mechanisms [3]. Therefore, some researchers have argued that the hypothesis suggesting that $A \beta$ directly causes $A D$ may not be correct [4]. They have proposed that focusing on the early stage of $\mathrm{AD}$ and implementing effective interventions are promising new treatment strategies [5]. Mitochondrial dysfunction occurs at the early stage of $\mathrm{AD}$, and it is considered to be an intracellular process that is severely compromised in $\mathrm{AD}$ [5-8]. On the other hand, mutations in $\beta$-amyloid precursor protein (APP) generate $A \beta$ [9], which leads to the accumulation of $A \beta$ on the mitochondrial membrane and ultimately causes mitochondrial dysfunction [10-13]. Mitochondrial dysfunction affects the production of reactive oxygen species (ROS) [14]; moreover, the molecular targets regulated by ROS, including mitochondrial DNA (mtDNA), calcium homeostasis, mitochondrial dynamics and function, and energy homeostasis, are affected by mitochondrial dysfunction [15-17]. Excessive ROS production exacerbates mitochondrial dysfunction, disrupts intracellular calcium balance, opens mitochondrial permeability transition pores (MPTPs), and leads to a decrease in mitochondrial membrane potential (MMP), thereby contributing to a vicious cycle $[17,18]$.

The term "mitochondrial dynamics" refers to fission and fusion in mitochondria, which play critical roles in mitochondrial dysfunction and the pathogenesis of $\mathrm{AD}$ $[15,19]$. An imbalance in mitochondrial dynamics significantly changes the expression levels of mitochondrial dynamics-related proteins, including dynamin-related protein 1 (Drp1), fission 1 (Fis1), mitofusin 1 (Mfn1), mitofusin 2 (Mfn2), and optic atrophy 1 (Opa 1) [20]. In addition, phosphorylation of Drp1 promotes mitochondrial division and leads to abnormal mitochondrial dynamics [21]. Therefore, it is possible to protect mitochondrial function by inhibiting the expression of p-Drp1 in mitochondria [22].

Some natural products, such as coenzyme Q10 and curcumin, have been reported to reduce $A \beta$ deposition in mitochondria, improve mitochondrial dysfunction, restore neuroplasticity, and improve cognitive dysfunction in patients [23]. Some Chinese medicine extracts have also been studied in this field, and they have shown promising effects for breakthrough treatments. Cynomorium songaricum Rupr (C. songaricum), a traditional Chinese medicine, is widely used to treat sexual disorders, such as erectile dysfunction and menstrual problems $[24,25]$. Our previous studies have shown that extract of C. songaricum (ECS) has neuroprotective effects in vivo and in vitro. It can alleviate the behavioral changes and morphological damage in animals with $\mathrm{AD}$ and resist the cytotoxicity induced by $\mathrm{A} \beta$ in vitro [2629]. Additionally, by ultrahigh-performance liquid chromatography and mass spectrometry (UPLC/LTQ-Orbitrap MS), we have identified that the main chemical components of ECS are B-type oligomeric forms of flavonoids [30]. However, the pharmacological effects and mechanisms of action of ECS on AD are not entirely clear. This study will identify whether ECS ameliorates $\mathrm{AD}$ in vitro by regulating mitochondrial dynamics homeostasis and maintaining the mitochondrial function of HT22 cells treated with $\mathrm{A} \beta$ and $\mathrm{H}_{2} \mathrm{O}_{2}$.

\section{Materials and methods}

\section{Standard solution and sample extraction}

The reference compounds phlorizin, isoquercitrin, and epicatechin (Yuanye Bio-Technology Corporation, Shanghai, China) were dissolved in $70 \%$ methanol (Fisher Corporation, Shanghai, China) and then stored at $4{ }^{\circ} \mathrm{C}$ for susequent qualitative analysis.

We obtained prepared slices of Cynomorium songaricum from the Chinese Medicine Clinic of Beijing University of Chinese Medicine. The extraction method of ECS was optimized based on our previous study [26]. Briefly, the plants were ground into a powder and sieved through $60 \mathrm{mesh}$, and then $500 \mathrm{~g}$ of the dried plant powder was extracted with $800 \mathrm{~mL}$ of methanol via ultrasound-assisted extraction (KQ 3200 dB, 100 W, 40 kHz, Kunshan, China) three times for $60 \mathrm{~min}$ each time. The three extracts were filtered and combined, and then the combined filtrate was evaporated in a rotary evaporator (RE 301, Shanghai, China) at $40^{\circ} \mathrm{C}$ to obtain a dry extract of methanol. Next, the dry extract was dissolved in $300 \mathrm{~mL}$ of water and successively extracted with dichloromethane and ethyl acetate three times to obtain ECS. The ECS was evaporated at $30^{\circ} \mathrm{C}$, and its dried extract was dissolved in $70 \%$ methanol and stored at $4{ }^{\circ} \mathrm{C}$ for quality analysis or dissolved in PBS for pharmacological study.

\section{HPLC analysis}

Apparatus and chromatographic conditions

The qualitative analysis was performed on a 1100 series High-Performance Liquid Chromatography (HPLC) 
system (Agilent, California, America). All the samples were analyzed at a column temperature of $30^{\circ} \mathrm{C}$ with a Kromasil C18 column $(4.6 \mathrm{~mm} \times 250 \mathrm{~mm}, 5 \mu \mathrm{m}$, Akzo Nobel, Sweden). The mobile phase consisted of eluents A (acetonitrile) and B ( $0.1 \%$ formic acid solution), and the optimized gradient elution model was as follows: 0 $20 \mathrm{~min}, 10-18 \%$ A; $20-30 \mathrm{~min}, 18-22 \%$ A; $30-45 \mathrm{~min}$, $22-40 \%$ A; $40-55 \mathrm{~min}, 40-70 \% \mathrm{~A}$. The flow rate was 0.8 $\mathrm{mL} / \mathrm{min}$, and $10 \mu \mathrm{L}$ of the sample was injected into the HPLC instrument each time. The detector scanned from $190 \mathrm{~nm}$ to $400 \mathrm{~nm}$, and the optimal detection wavelength was $280 \mathrm{~nm}$.

\section{Validation of the method}

According to ICH guidelines, the analytical method was determined with suitable levels of sample linearity, precision, and accuracy [31]. All calibration curves were established by using six different concentrations of mixed standards.

\section{Cell culture and treatment}

HT22 mouse hippocampal neuronal cells were cultured in Dulbecco's modified Eagle's medium (DMEM, Gibco, USA) supplemented with $10 \%$ fetal bovine serum (FBS, Gibco) and 1\% penicillin-streptomycin solution (Invitrogen, USA) at $37^{\circ} \mathrm{C}$ in a $5 \% \mathrm{CO}_{2}$ incubator.

HT22 cells were pretreated with ECS for $2 \mathrm{~h}$, and then A $\beta_{25-35}$ or hydrogen peroxide $\left(\mathrm{H}_{2} \mathrm{O}_{2}\right)$ was added to the final concentration (see below). $A \beta_{25-35}$ plaques were generated as described in a previous method [32]. Briefly, $A \beta_{25-35}$ monomers were dissolved in distilled water to a stock concentration of $1 \mathrm{mmol} / \mathrm{L}$, incubated at $37^{\circ} \mathrm{C}$ for 7 days, and then stored as $\mathrm{A} \beta_{25-35}$ plaques at $-20^{\circ} \mathrm{C}$ for later use.

\section{Cell viability assay}

HT22 cells were seeded in 96-well plates at a density of $5 \times 10^{3}$ cells/well and pretreated with a series of concentrations of ECS from 20 to $800 \mu \mathrm{g} / \mathrm{mL}$ for $2 \mathrm{~h}$. Then, certain concentrations of $\mathrm{A} \beta_{25-35}$ and $\mathrm{H}_{2} \mathrm{O}_{2}$ were added and cocultured with ECS for another $22 \mathrm{~h}$. Cell viability in response to the different treatments was measured using a cell counting kit-8 (CCK-8) (Dojindo, Japan). Briefly, after each treatment, $10 \mu \mathrm{L}$ of CCK- 8 solution was added to each well and incubated for $2 \mathrm{~h}$. The absorbance in each well was read at $450 \mathrm{~nm}$ on a microplate reader (Thermo Fisher Scientific, USA). Cell viability was determined using the following equation: Cell viability $(\%)=($ Mean $\mathrm{OD}$ drug-treated cells $) /($ Mean OD untreated cells $) \times 100 \%$.

\section{Transmission electron microscopy (TEM)}

After ECS treatment, cells were collected with trypsinization, washed three times with phosphate-buffered saline (PBS, Corning, USA), and then fixed in a $2.5 \%$ glutaraldehyde solution at $4{ }^{\circ} \mathrm{C}$ overnight. The glutaraldehyde solution was discarded, and the cells were washed three times with PBS. The cells were postfixed with $1 \%$ osmium tetroxide for $3 \mathrm{~h}$, stained with $2 \%$ uranyl acetate at $4{ }^{\circ} \mathrm{C}$, dehydrated in a graded ethanol series with concentrations ranging from 50 to $100 \%$, and embedded in Spurr resin. Ultrathin $(60 \mathrm{~nm})$ sections were stained with $3 \%$ uranyl acetate and lead citrate and then examined by TEM (JEM-1400Plus).

\section{Flow cytometric analysis}

We applied an oxidation-sensitive fluorescent probe, $2^{\prime}, 7^{\prime}$-dichlorofluorescein diacetate (DCFH-DA), from an assay kit (Beyotime Biotechnology, Beijing, China) to label intracellular ROS and detected the $2^{\prime}, 7^{\prime}$-dichlorofluorescein (DCF) intensity by flow cytometry. Briefly, HT22 cells were seeded into six-well plates at a density of $2 \times 10^{5}$ cells/well and treated as described above. After treatment, the cells were washed twice in PBS, collected, adjusted to $1 \times 10^{6}$ cells $/ \mathrm{mL}$, and incubated with DCFHDA at $37^{\circ} \mathrm{C}$ for $20 \mathrm{~min}$. DCFH-DA was intracellularly deacetylated by a nonspecific esterase, which was further oxidized by ROS to produce the fluorescent compound 2,7-dichlorofluorescein (DCF). The fluorescence intensity of DCF was detected by flow cytometry (BD FACSCalibur, USA), and the stained cells emitting fluorescence were measured using channel FL-1. The results were measured as the relative mean fluorescence intensity of FL-1 of the control group [33].

\section{Western blot analysis}

After treatment, HT22 cells were lysed in radioimmunoprecipitation assay (RIPA) buffer (Sigma-Aldrich, USA) supplemented with a protease inhibitor cocktail (Roche Diagnostics, Shanghai, China). Total protein quantification and western blot procedures were performed routinely [34]. Then, equal amounts of proteins were resolved by sodium dodecyl sulfate-polyacrylamide gel electrophoresis (SDS-PAGE) and transferred onto polyvinylidene difluoride (PVDF) membranes. The membranes were incubated with blocking buffer, $5 \%$ nonfat milk, or 5\% BSA (for phosphoproteins) for $1.5 \mathrm{~h}$. Then, the membranes were incubated with primary antibodies against Drp-1, Mfn1, Mfn2, Fis1, $\beta$-actin (Proteintech, Wuhan, China), p-Drp1 (Ser637), and Opa1 (Cell Signaling Technology, CST, USA). After that, the membranes were incubated with corresponding secondary antibodies, namely, goat anti-rabbit IgG or goat anti-mouse IgG (Proteintech, Wuhan, China). The proteins were detected using an enhanced chemiluminescence (ECL) kit (Thermo Fisher Scientific, USA) and visualized by a chemiluminescence imaging system (Azure 300, Azure Biosystems, USA). 


\section{Fluorospectrophotometry}

The intracellular ATP level was measured using a luminescent ATP detection assay kit (Beyotime, Beijing, China) according to the kit protocol. Briefly, the medium was discarded, and the cells were washed three times with PBS. Then, 1\% Triton X-100 (Sigma, USA) was added to lysed cells, and the cells were incubated for 30 min. Finally, $90 \mu \mathrm{L}$ of ATP assay kit reagent was added to $10 \mu \mathrm{L}$ of cell lysate in each well of the 96-well plates, and luminescence was measured by a fluorospectrophotometer.

\section{Fluorescence microscopy analysis}

Fluo-4 acetoxymethyl ester (Fluo-4-AM) (Beyotime, Beijing, China) dye was used to measure intracellular calcium. HT22 cells were seeded into 6-well plates at a density of $2 \times 10^{5}$ cells/well and treated as described above. After treatment, the cells were stained with Fluo4-AM diluted to a concentration of $2.5 \mu \mathrm{M}$ for $30 \mathrm{~min}$ in darkness at $37^{\circ} \mathrm{C}$ and then washed with Dulbecco's phosphate-buffered saline (DPBS) three times. The green fluorescence, which reflected the intracellular calcium level, was recorded by a fluorescence microscope (Olympus, Japan).

An MMP assay kit with JC-1 (Beyotime, Beijing, China) was used. The kit resulted in the formation of JC-1 aggregates that emitted red fluorescence at a high MMP, while monomers that emitted green fluorescence at low MMP were produced when they selectively entered the mitochondria. After treatment as described, the cells in different groups were washed with PBS twice and then incubated with $2 \mu \mathrm{M} \mathrm{JC}-1$ in fresh culture medium under permissive conditions. After $30 \mathrm{~min}$, the cells were washed with PBS three times and resuspended in culture medium. Red and green fluorescence was detected by a fluorescence microscope (Olympus, Japan).

\section{Statistical analysis}

The statistical analyses were performed using SPSS 22.0 software (SPSS Inc., Chicago, USA). All data from the cell experiments are presented as the mean \pm SE. The statistical significance was analyzed with one-way analysis of variance (ANOVA) followed by Tukey's HSD post hoc test, and $P<0.05$ was considered to indicate statistical significance.

\section{Results}

\section{Validation of the quantitative analysis method}

The quantitative method involved determination of linearity, the LOD, the LOQ, precision, reproducibility, stability, and recovery. Three standards, epicatechin, phlorizin, and isoquercitrin, were used to obtain reference peaks to validate the method (Fig. 1). Standard curves and linearity were generated by plotting the peak areas $(y)$ against the compound concentrations $(x, \mu g$ $\mathrm{mL}^{-1}$ ), which were obtained as shown in Table 1 . There was good linearity within a wide concentration range. The LOD (signal/noise $=3$ ) and LOQ (signal/noise = 10) values of the three compounds were also calculated and found to be within the ranges of $0.0317-0.0655 \mu \mathrm{g} / \mathrm{mL}$ and $0.0944-0.1567 \mu \mathrm{g} / \mathrm{mL}$, respectively.

Six repeated injections of the same sample were used to evaluate repeatability, and gradient dilutions of six concentrations of the standard compounds was used to validate their precision. The relative standard deviations (RSDs) of the reference peaks were $0.33-0.39 \%$ and $0.65-1.12 \%$, respectively. The stability of the sample solutions was evaluated by injecting the same sample at 0 , $2,4,8,12$, and $24 \mathrm{~h}$. The RSD of stability was less than $1 \%$, indicating that the solution remained stable within $24 \mathrm{~h}$. The recovery of the three compounds was evaluated by adding the same amounts of the standards to a certain amount of sample. As shown in Table 2, the recovery of the three compounds was $98-103 \%$, and the RSDs of recovery ranged from 0.54 to $1.1 \%$. These results suggested that the optimized method was suitable for the following quantitative and qualitative analyses.

\section{Effects of ECS on HT22 cell viability in two models}

The effects of different concentrations and administration times of ECS on the viability of HT22 cells were examined, and the optimal administration concentration of ECS was determined to be $200 \mu \mathrm{g} / \mathrm{mL}$, while the optimal action time was $24 \mathrm{~h}$ (supplement file, Fig. S1). Furthermore, $20 \mu \mathrm{M} \mathrm{A} \beta$ and $200 \mu \mathrm{M} \mathrm{H}_{2} \mathrm{O}_{2}$ were used to mimic the AD model in vitro (supplement file, Fig. S2, Fig. S3).

As shown in Fig. 2, $100 \mu \mathrm{g} / \mathrm{mL}$ and $200 \mu \mathrm{g} / \mathrm{mL}$ ECS significantly improved the cell viability of the A $\beta$ exposed cells $(* P<0.05)$, which exhibited cell viabilities of $116.63 \pm 18.65 \%$ and $136.48 \pm 1.40 \%$, respectively. Therefore, $200 \mu \mathrm{g} / \mathrm{mL}$ ECS was used to treat HT22 cells induced by $A \beta$ in subsequent experiments. In the $\mathrm{H}_{2} \mathrm{O}_{2}$ induced model, $200 \mu \mathrm{g} / \mathrm{mL}$ ECS significantly improved cell viability $\left(102.19 \pm 14.10 \%,{ }^{*} P<0.05\right)$. Thus, $200 \mu \mathrm{g} /$ mL ECS was determined to be effective in $\mathrm{H}_{2} \mathrm{O}_{2}$-exposed cells.

\section{Beneficial effects of ECS on mitochondrial ultrastructures} We examined mitochondrial ultrastructures after treatment in $\mathrm{A} \beta$ - and $\mathrm{H}_{2} \mathrm{O}_{2}$-exposed cells using TEM. As shown in Fig. 3, the mitochondria in the control and ECS-treated groups exhibited double membranes and neatly arranged lamellar mitochondrial crests. However, in the $\mathrm{A} \beta$ - and $\mathrm{H}_{2} \mathrm{O}_{2}$-exposed groups, the mitochondria accumulated damaged and divided fragments and even autophagosomes. ECS ameliorated the damage to the mitochondrial ultrastructure in $\mathrm{A} \beta$ - and $\mathrm{H}_{2} \mathrm{O}_{2}$-exposed cells. After treatment, the autophagosomes disappeared, 


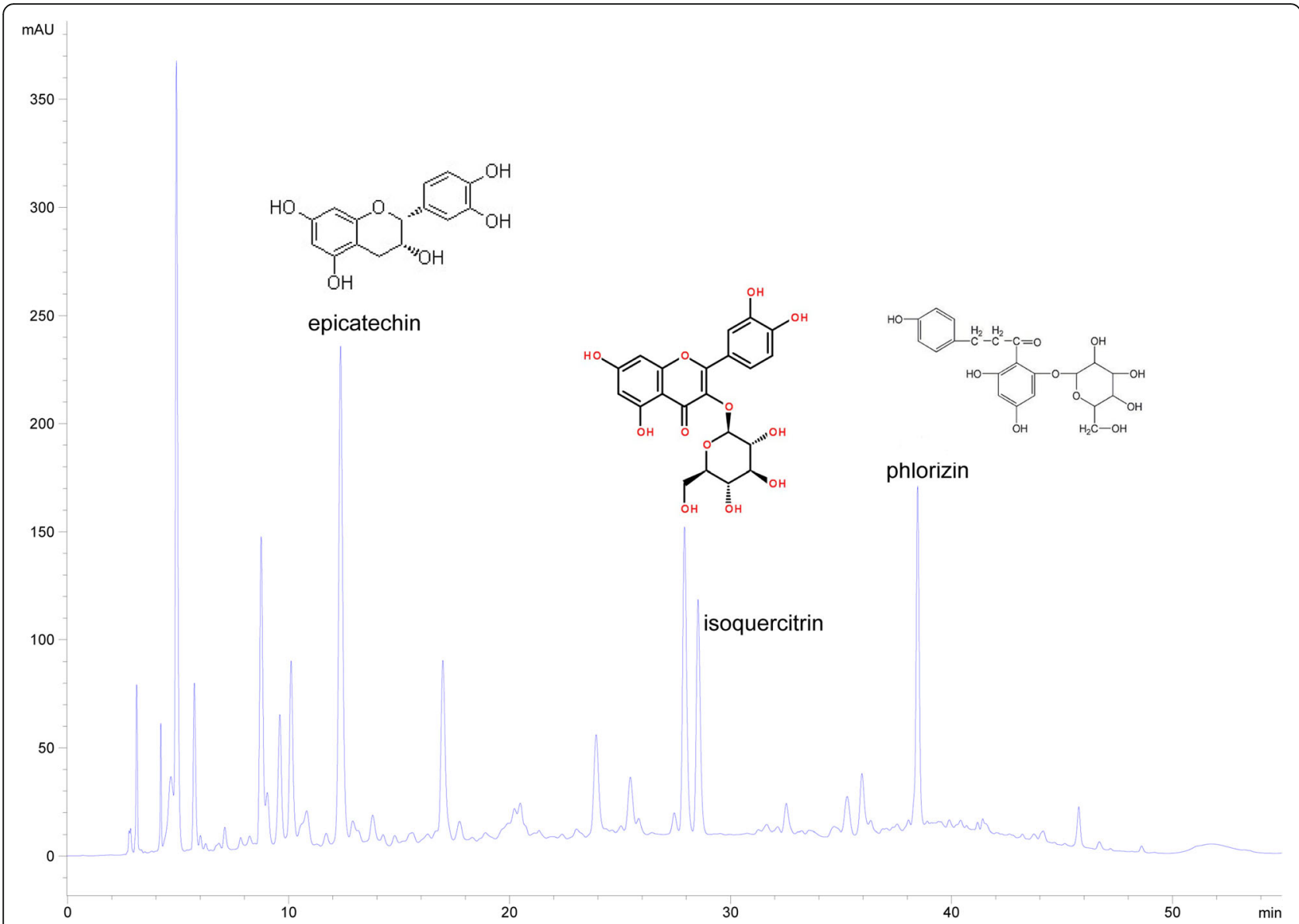

Fig. 1 Chemical structures of the standard compounds and the chromatogram of ECS. Quantitative analysis of ECS was performed by HPLC, and the three compounds, epicatechin, isoquercitrin, and phlorizin, were labeled in the chromatogram of ECS based on the relative retention times of their standards

and mitochondrial cristae were clearly observed in these two models.

\section{Improvements in intracellular ATP levels}

The calibration curve between the concentration of the ATP standard and its absorbance is shown in Fig. 4A and showed good linearity $\left(R^{2}=0.9958\right)$. In the $\mathrm{A} \beta$ - and $\mathrm{H}_{2} \mathrm{O}_{2}$-exposed groups, the concentrations of ATP were $0.176 \pm 0.014 \mu \mathrm{M}$ and $0.170 \pm 0.008 \mu \mathrm{M}$, respectively, indicating that $A \beta$ and $\mathrm{H}_{2} \mathrm{O}_{2}$ can cause significant decreases in ATP levels in normal HT22 cells. However, there was no significant difference between the $A \beta$ - and $\mathrm{H}_{2} \mathrm{O}_{2}$-exposed cells. After treatment with ECS, the concentrations of intracellular ATP significantly increased in the two models and were even at the same levels as those in the normal cells.

\section{Regulatory effects of ECS on ROS}

The relative value of ROS in each group is the ratio of the average fluorescence intensity of that group to the fluorescence intensity in the control group (Fig. 5). The results showed that the relative ROS levels in the $A \beta$ and $\mathrm{H}_{2} \mathrm{O}_{2}$-exposed cells were $1.36 \pm 0.11$ and $1.25 \pm 0.08$, respectively, which were significantly higher than those in the normal cells. However, there was no significant difference between $A \beta$-exposed and $\mathrm{H}_{2} \mathrm{O}_{2}$-exposed cells.

Table 1 Linearity, the limits of detection (LOD), and the limits of quantification (LOQ) for the three compounds

\begin{tabular}{llllll}
\hline Compounds & Calibration curve $^{\mathbf{a}}$ & $\mathbf{R}^{\mathbf{b}}$ & Linear range $(\boldsymbol{\mu g} / \mathbf{m L})$ & LOD $(\boldsymbol{\mu g} / \mathbf{m L})$ & $\mathbf{L O Q}(\boldsymbol{\mu g} / \mathbf{m L})$ \\
\hline epicatechin & $y=652.34 x+3.0036 y$ & 0.9999 & $4.50-144$ & 0.0427 & 0.0944 \\
phlorizin & $y=1858.9 x-48.333$ & 1.0000 & $3.68-117.6$ & 0.0655 & 0.7704 \\
isoquercitrin & $y=1304.4 X-10.637$ & 0.9998 & $2.77-177.3$ & 0.0317 & 0.1567
\end{tabular}

${ }^{a} \mathrm{y}$, peak area; $\mathrm{x}$, compounds concentration $(\mu \mathrm{g} / \mathrm{mL}){ }^{\mathrm{b}} \mathrm{R}$, correlation coefficient, $n=6$ 
Table 2 Precisions, Repeatability, Stability and Recovery of the three standard compounds

\begin{tabular}{llllll}
\hline Compounds & $\begin{array}{l}\text { Precisions } \\
\text { RSD }(\%)(\boldsymbol{n}=\mathbf{6})\end{array}$ & $\begin{array}{l}\text { Repeatability } \\
\text { RSD }(\%)(\boldsymbol{n}=\mathbf{6})\end{array}$ & $\begin{array}{l}\text { Stability } \\
\text { RSD }(\%)(\boldsymbol{n}=\mathbf{6})\end{array}$ & Recovery (\%) $(\boldsymbol{n}=\mathbf{9})$ & RSD (\%) \\
\hline epicatechin & 0.33 & 1.12 & 0.33 & 98.54 & 1.1 \\
phlorizin & 0.39 & 0.65 & 0.38 & 102.47 & 0.54 \\
isoquercitrin & 0.21 & 1.31 & 0.22 & 102.71 & 0.89 \\
\hline
\end{tabular}

The relative ROS levels in the two treated groups were significantly lower than those in the two model groups. ECS did not significantly change the relative value of ROS in the normal cells.

\section{Beneficial effects of ECS on the MMP}

MMP was observed in HT22 cells by using the mitochondrial membrane fluorescent dye JC-1. Green fluorescence was emitted when the MMP was low, while red fluorescence was emitted when the MMP was high. The red and green fluorescent signals are presented in Fig. 6A. The $\mathrm{red} /$ green fluorescent signal ratios in $\mathrm{A} \beta$ - and $\mathrm{H}_{2} \mathrm{O}_{2}$-exposed cells were significantly lower than those in the control cells, indicating significant decreases in MMP in these two models $\left({ }^{\#} P<0.05\right)$. ECS improved MMP in the two model groups $\left({ }^{\mathrm{a}} \mathrm{P}<0.05{ }^{\mathrm{b}} \mathrm{P}<0.05\right)$ (Fig. 6B).

\section{Regulatory effects of ECS on mitochondrial dynamics- related proteins}

The results showed that the expression of Drp1 in the ECS group was significantly lower than that in the control group
${ }^{\#} P<0.05$ ) (Fig. 7). The expression levels of Drp1 in the A $\beta$ and $\mathrm{H}_{2} \mathrm{O}_{2}$-exposed models were significantly higher than that in the control group ( ${ }^{*} P<0.05$ ), but there was no significant difference between the two model groups. ECS significantly decreased the expression of Drp1 in $\mathrm{A} \beta$ - and $\mathrm{H}_{2} \mathrm{O}_{2}$ exposed cells ( ${ }^{\mathrm{a}} \mathrm{P}<0.05$; ${ }^{\mathrm{b}} \mathrm{P}<0.05$ ). With regard to the expression level of $\mathrm{p}$-Drp1, there were no significant differences in $\mathrm{A} \beta$ - and $\mathrm{H}_{2} \mathrm{O}_{2}$-exposed cells compared with normal cells, but ECS significantly decreased the expression of p-Drp1 in both the control group and the two model groups $\left({ }^{\#} P<0.05\right.$; $\left.{ }^{\mathrm{a}} \mathrm{P}<0.05 ;{ }^{\mathrm{b}} \mathrm{P}<0.05\right)$. In the $\mathrm{A} \beta$ and $\mathrm{H}_{2} \mathrm{O}_{2}$ models, the $\mathrm{p}-$ Drp1/Drp1 ratios were significantly lower than that in the control group ( $\left.{ }^{\#} P<0.05\right)$, and ECS treatment significantly increased the p-Drp1/Drp1 ratios in the two model groups ( $\left.{ }^{\mathrm{a}} \mathrm{P}<0.05,{ }^{\mathrm{b}} \mathrm{P}<0.05\right)$. Another interesting result was that ECS treatment increased the $\mathrm{p}$-Drp1/Drp1 ratio in the $\mathrm{H}_{2} \mathrm{O}_{2}$ model $\left({ }^{\#} P<0.05\right)$.

ECS also inhibited excessive mitochondrial fission in $\mathrm{H}_{2} \mathrm{O}_{2}$-exposed cells. The results showed that the expression levels of Fis1 in $\mathrm{H}_{2} \mathrm{O}_{2}$-exposed cells were significantly higher than those in normal cells $\left({ }^{\#} P<0.05\right)$,

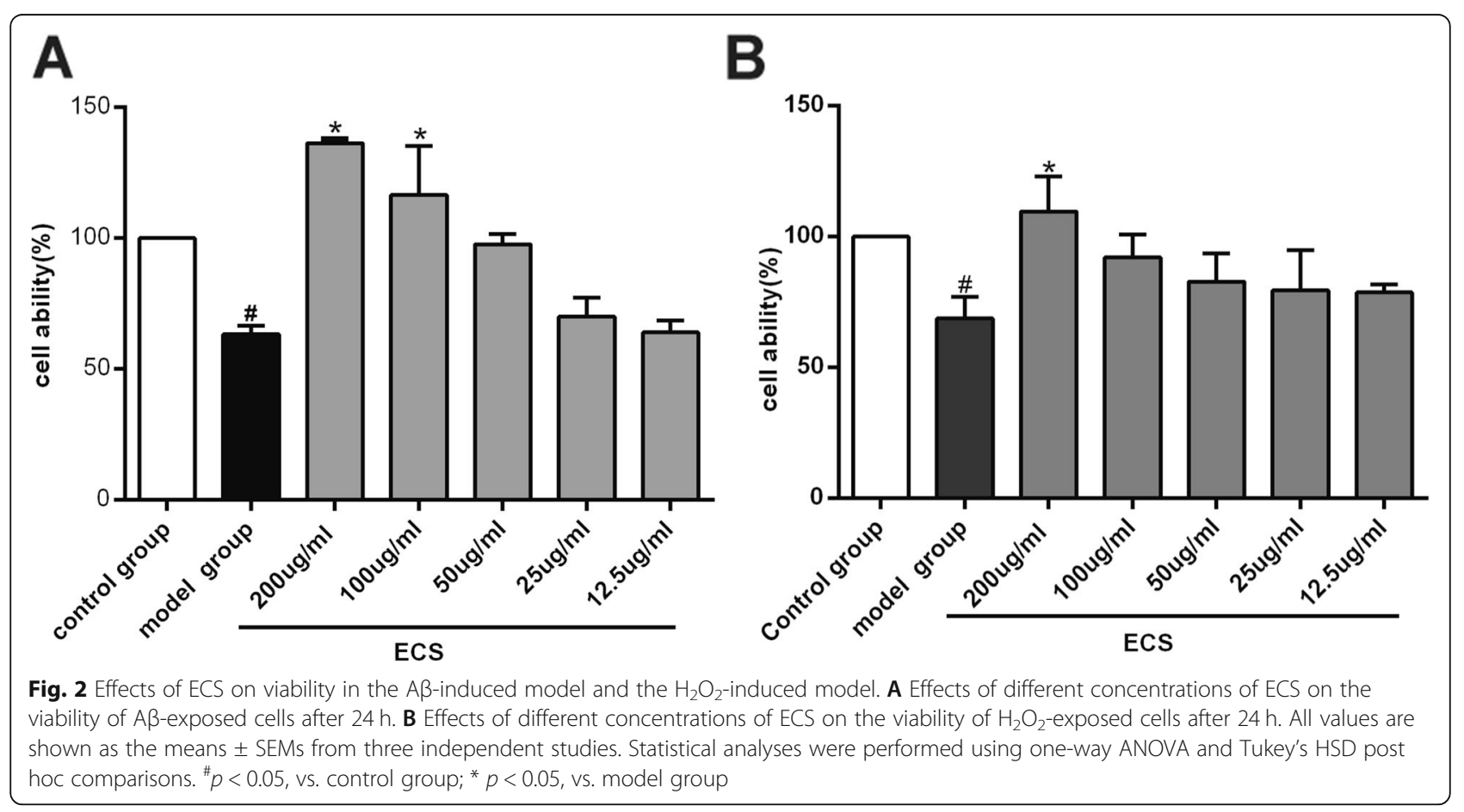



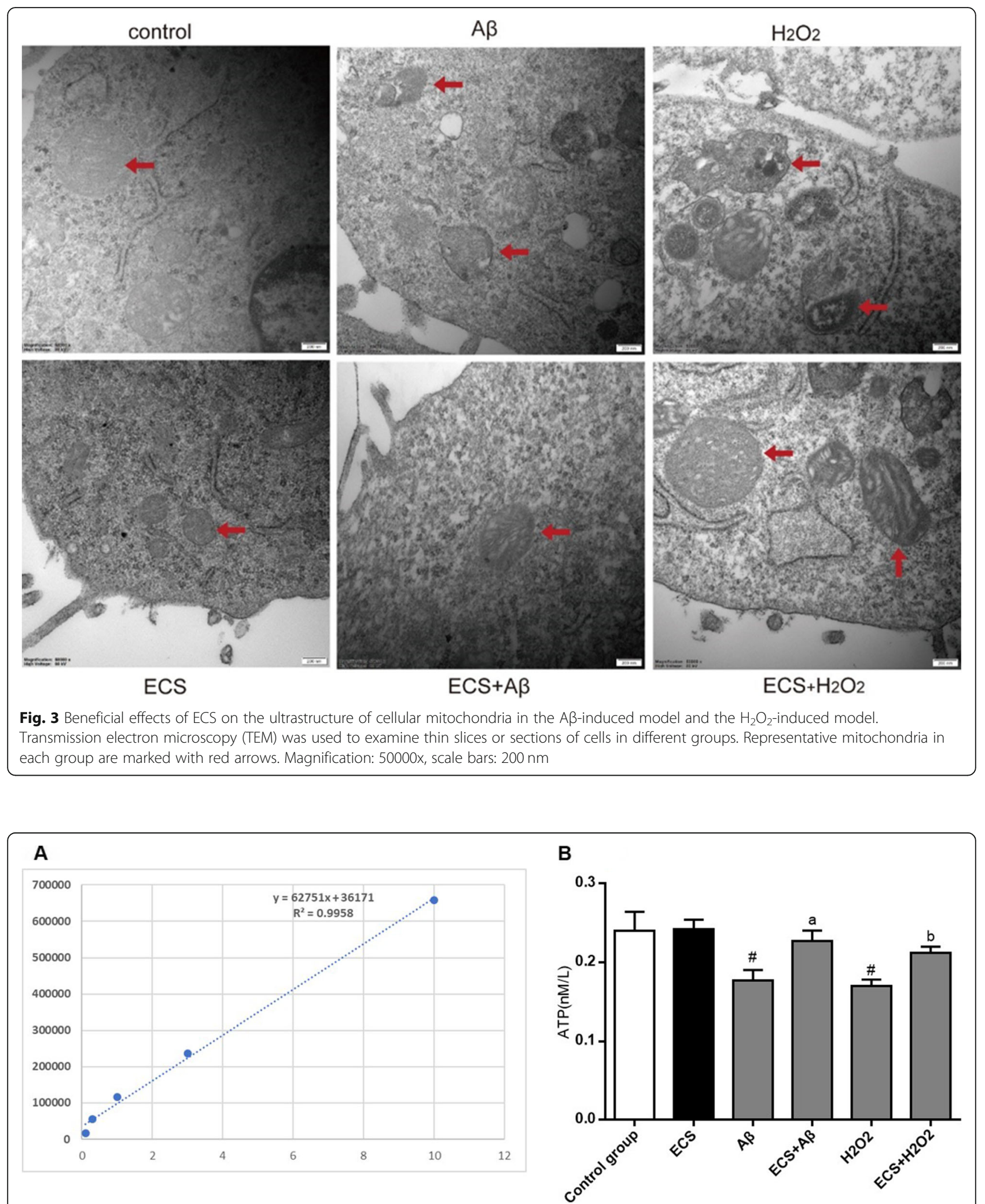

Fig. 4 Beneficial effects of ECS on the intracellular ATP levels in the Aß-induced model and the $\mathrm{H}_{2} \mathrm{O}_{2}$-induced model. A Standard curve between the concentration of ATP standard and its absorbance. $R^{2}=0.9958$, indicating good linearity. $\mathbf{B}$ Changes in intracellular ATP among the six groups. All values are shown as the means \pm SEMs from three independent studies. Statistical analyses were performed using one-way ANOVA and Tukey's HSD post hoc comparisons. ${ }^{\#} p<0.05$, vs. control group; ${ }^{a} P<0.05$, vs. A $\beta$ model group; ${ }^{b} p<0.05$, vs. $\mathrm{H}_{2} \mathrm{O}_{2}$ model 

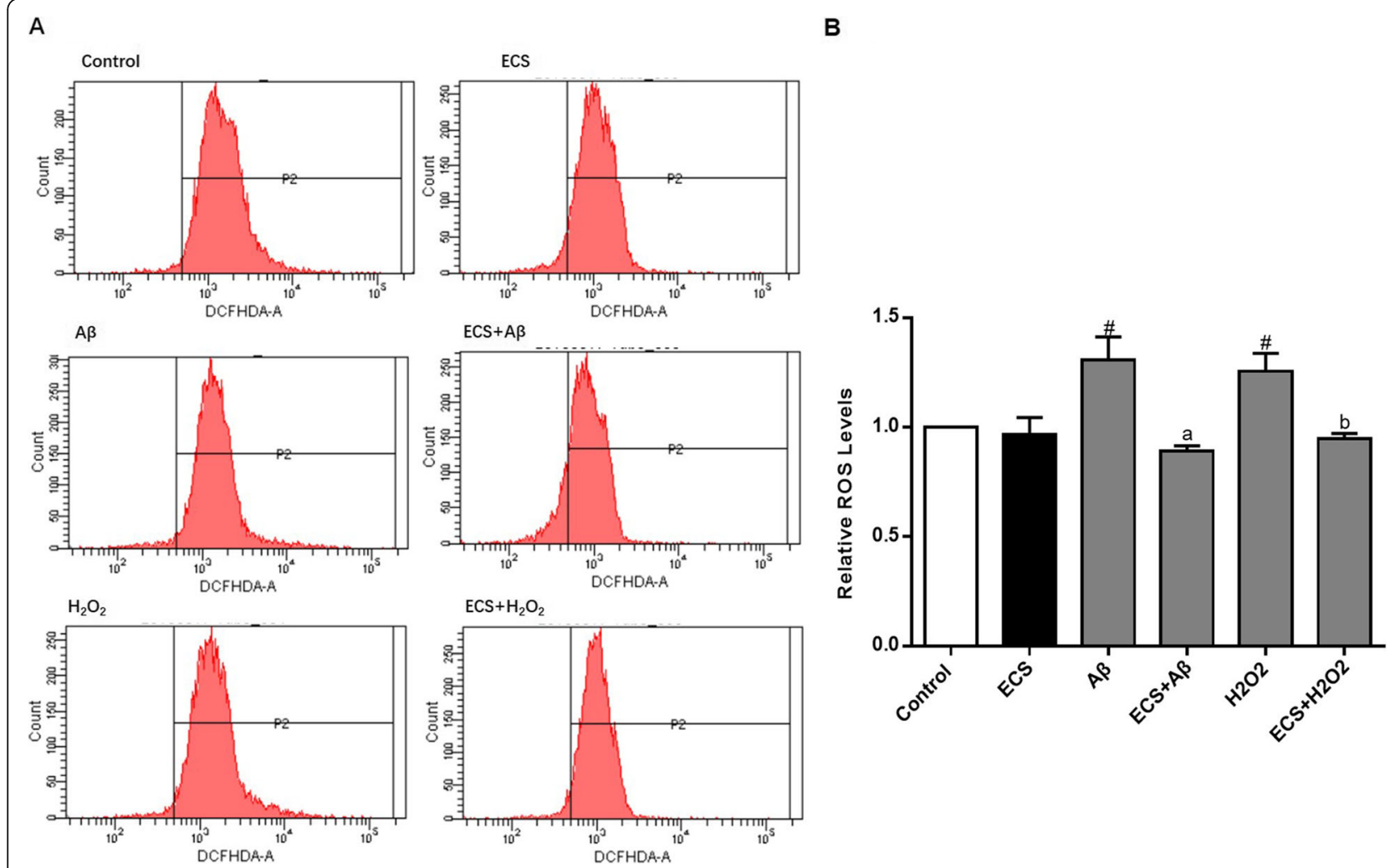

Fig. 5 The regulation of intracellular ROS by ECS in the Aß-induced model and $\mathrm{H}_{2} \mathrm{O}_{2}$-induced model. A The results of flow cytometry. B The relative level of intracellular ROS in each group compared with the control group. All values are shown as the mean \pm SEM from three independent studies. Statistical analyses were performed using one-way ANOVA and Tukey's HSD post hoc comparisons. ${ }^{\#} p<0.05$, vs. control group; ${ }^{a} P<0.05$, vs. A $\beta$ model group; ${ }^{b} P<0.05$, vs. $\mathrm{H}_{2} \mathrm{O}_{2}$ model

while the levels in $\mathrm{A} \beta$-exposed cells were not significantly different. ECS significantly decreased the expression levels of Fis1 in both normal cells and $\mathrm{H}_{2} \mathrm{O}_{2-}$ exposed cells $\left({ }^{\#} P<0.05,{ }^{b} P<0.05\right)$. Interestingly, the expression levels of Fis1 in $\mathrm{H}_{2} \mathrm{O}_{2}$-exposed cells were higher than those in $\mathrm{A} \beta$-exposed cells; this pattern was quite different from the expression patterns of other mitochondrial dynamics-related proteins.

ECS had no significant regulatory effects on the expression of the mitochondrial fusion proteins Opa1, Mfn1, and Mfn2 but showed a tendency to reduce the expression levels of fusion proteins.

\section{Mechanisms by which ECS regulates mitochondrial kinetic balance in the AD model \\ Changes in intracellular calcium ion concentrations in the $A \beta$ and $\mathrm{H}_{2} \mathrm{O}_{2}$ models}

The intracellular calcium ion concentration $\left(\left[\mathrm{Ca}^{2+}\right] i\right)$ was detected with a fluorescence microscope, and the fluorescence intensity was analyzed using ImageJ software. The $\left[\mathrm{Ca}^{2+}\right] i$ in each group was compared to the concentration in the control group. The results showed that the $\left[\mathrm{Ca}^{2+}\right] i$ values in $\mathrm{A} \beta$-exposed cells $(1.29 \pm 0.11)$ and $\mathrm{H}_{2} \mathrm{O}_{2}$-exposed cells $(1.22 \pm 0.03)$ were significantly higher than those in normal cells $\left({ }^{\#} P<0.01\right)$, but there was no significant difference between the two model groups (Fig. 8). ECS significantly decreased $\left[\mathrm{Ca}^{2+}\right] i$ in A $\beta$-exposed cells and $\mathrm{H}_{2} \mathrm{O}_{2}$-exposed cells to $0.88 \pm 0.03$ $\left({ }^{\mathrm{a}} P<0.01\right)$ and $0.92 \pm 0.05\left({ }^{\mathrm{b}} P<0.01\right)$, respectively. Similarly, FK506, an inhibitor of calcium ion channels, also significantly decreased $\left[\mathrm{Ca}^{2+}\right] i$ in the $A \beta$-exposed cells and $\mathrm{H}_{2} \mathrm{O}_{2}$-exposed cells $\left(0.94 \pm 0.02\right.$, ${ }^{\mathrm{a}} \mathrm{P}<0.01$; and $1.03 \pm 0.61,{ }^{\mathrm{b}} P<0.05$, respectively), suggesting that ECS and FK506 exert similar pharmacological effects, reducing intracellular calcium ion concentrations.

\section{Effects of ECS and FK-506 on the expression of mitochondrial kinetics-related proteins and calcineurin in $A \beta$ and $\mathrm{H}_{2} \mathrm{O}_{2}$ models}

To evaluate the effects of intracellular calcium ions on mitochondrial dynamics in the AD models, we detected the expression level of $\mathrm{CaN}$, the intracellular calcium ion concentration, and the phosphorylation of Drp1 (Ser637) after FK506 intervention (Fig. 9). The expression levels of $\mathrm{CaN}$ were significantly higher in the $\mathrm{A} \beta$ - and $\mathrm{H}_{2} \mathrm{O}_{2}$ exposed cells than in the normal cells $\left({ }^{\#} P<0.05\right)$, and the $\mathrm{CaN}$ expression levels in the $\mathrm{H}_{2} \mathrm{O}_{2}$-exposed cells were slightly higher than those in the $\mathrm{A} \beta$-exposed cells, 


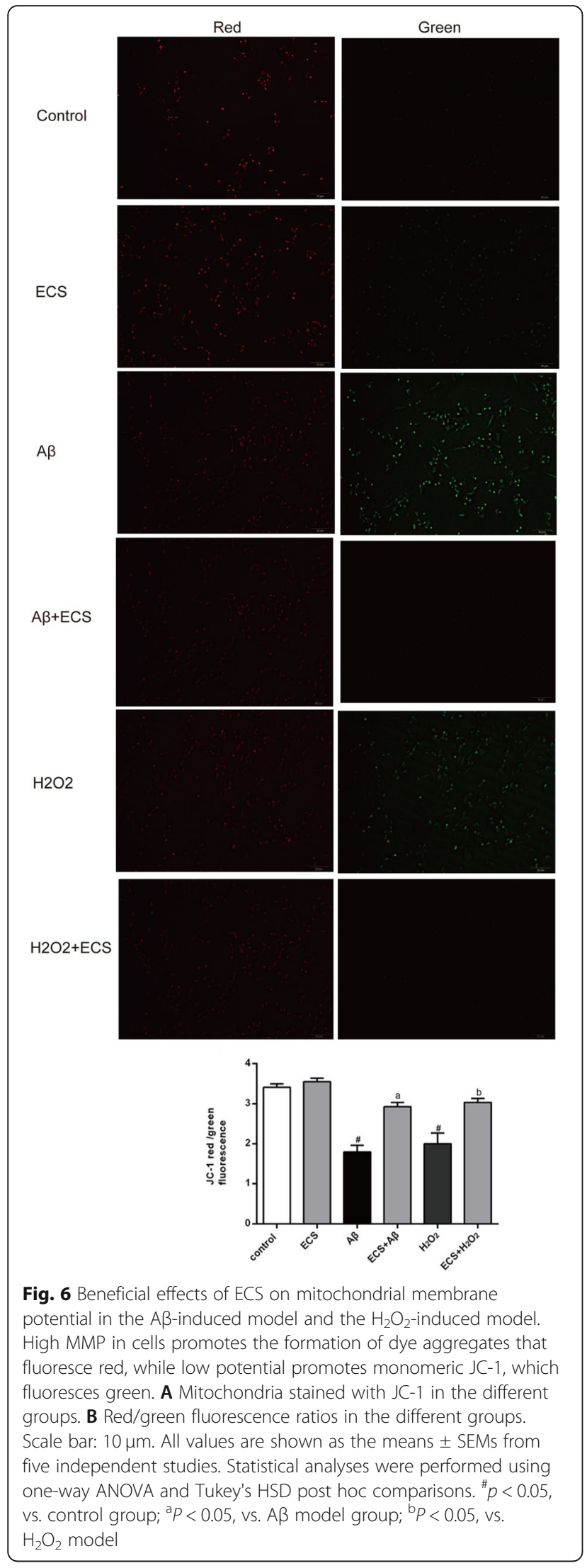

although the difference was not significant. Additionally, administration of ECS significantly decreased the expression levels of $\mathrm{CaN}$ in the two model groups $\left({ }^{\mathrm{a}} \mathrm{P}<0.05\right.$, $\left.{ }^{\mathrm{b}} P<0.05\right)$, and administration of FK-506, which had effects similar to those of ECS, significantly reduced the expression of $\mathrm{CaN}$ in the $\mathrm{A} \beta$ - and $\mathrm{H}_{2} \mathrm{O}_{2}$-exposed cells $\left({ }^{\mathrm{a}} P<0.05,{ }^{\mathrm{b}} P<0.05\right)$.

FK-506 also significantly decreased the expression levels of Drp1 and p-Drp1 in A $\beta$ - and $\mathrm{H}_{2} \mathrm{O}_{2}$-exposed cells $\left({ }^{\mathrm{a}} P<0.05,{ }^{\mathrm{b}} P<0.05\right)$, similar to ECS. In addition, FK-506 significantly decreased the p-Drp1/Drp1 ratios in $\mathrm{A} \beta$ - and $\mathrm{H}_{2} \mathrm{O}_{2}$-exposed cells $\left({ }^{\mathrm{a}} \mathrm{P}<0.05,{ }^{\mathrm{b}} \mathrm{P}<0.05\right)$, indicating that both ECS and FK-506 can significantly reduce the phosphorylation of Drp1 at serine 637.

\section{Discussion}

HT22 is a subline cloned from the HT4 line of immortalized mouse hippocampal neural precursor cells. It is a valuable cell model for studies on neurodegenerative diseases, such as Alzheimer's disease [35, 36]. Thus, HT22 cells were used to establish AD models in vitro in this study.

$\mathrm{A} \beta$ can induce an $\mathrm{AD}$ model because it exerts toxic effects on neuronal cells [37]. Studies have shown that accumulated $A \beta$ on the mitochondrial membrane interacts with mitochondrial matrix components, leading to the degeneration of neuronal synapses [10]. Several studies have shown that $A \beta$ causes intracellular accumulation of ROS and ultimately leads to DNA damage [38]. Meanwhile, ROS cause oxidative stress when their production is higher than their elimination [39]. Therefore, oxidative stress induced by ROS may play a crucial role in the pathogenesis of $\mathrm{AD}$ and underlie the mechanism of $\mathrm{A} \beta$ induced neurotoxicity. As ROS and $\mathrm{H}_{2} \mathrm{O}_{2}$ cause oxidative stress, targeting oxidative stress can be considered a therapeutic strategy to ameliorate neurotoxicity in AD.

The mitochondrion is a cellular organelle with a characteristic structure separated from the cytoplasm by the outer and inner mitochondrial membranes. The inner membrane forms invaginations called cristae, which are the main sites of bioenergy transformation in eukaryotes [40]. Early studies demonstrated fragmentation of the mitochondrial network in the AD brain that could cause mitochondrial bioenergetic deficits through mechanisms such as enhancement of ROS generation [41, 42]. This study found that hyperfusion of damaged mitochondria or fragmentation of mitochondria induced by fission occurred in $\mathrm{A} \beta$ - and $\mathrm{H}_{2} \mathrm{O}_{2}$-exposed cells. After being treated with ECS, the cells exhibited normal-appearing mitochondria. The lamellar mitochondrial cristae were clearly and neatly arranged, indicating that ECS ameliorated the damage to the mitochondrial ultrastructure.

Mitochondrial morphological alterations are often accompanied by mitochondrial dysfunction [43]. Some 


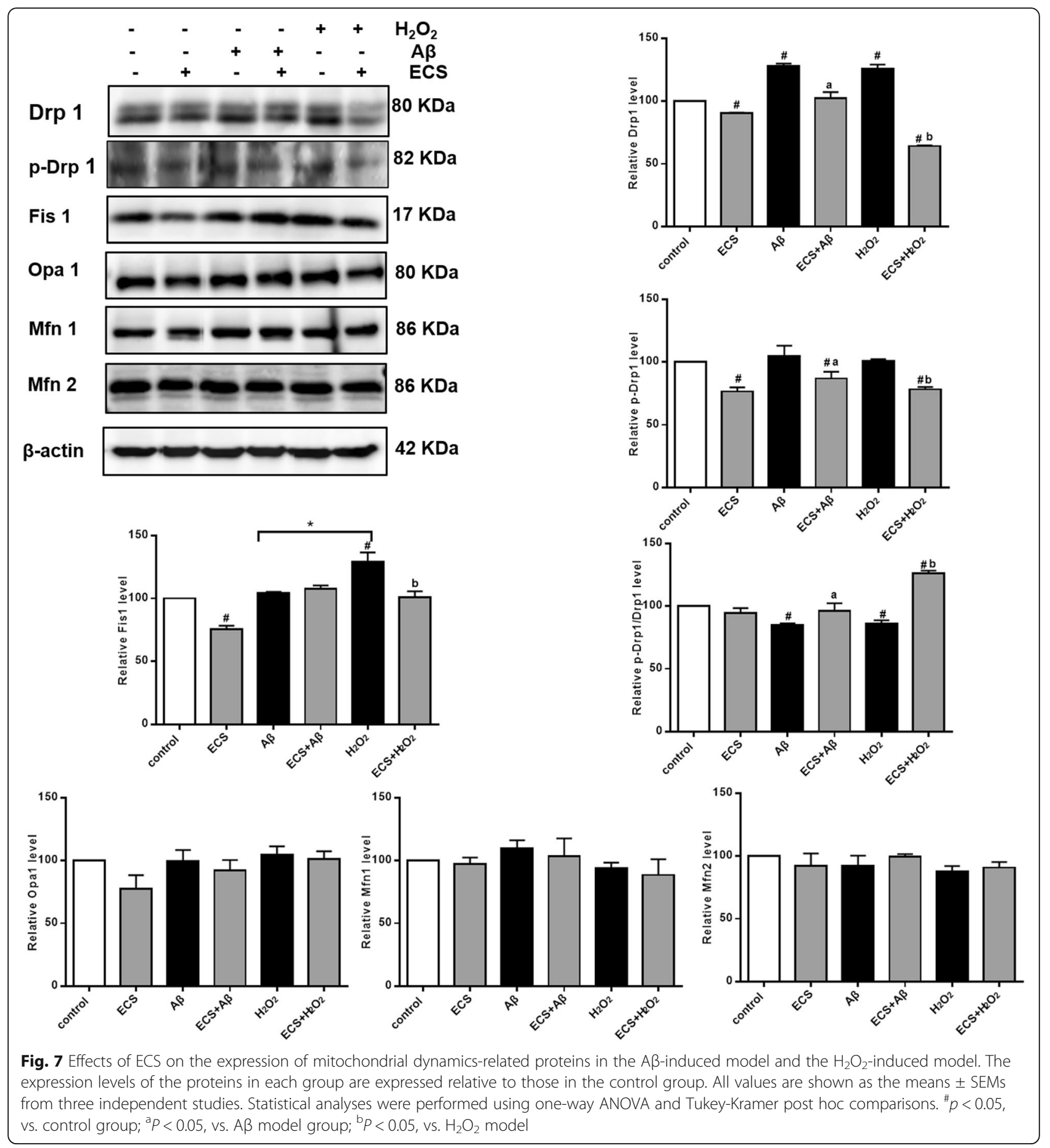

studies have suggested that $\mathrm{A} \beta$ and $\mathrm{H}_{2} \mathrm{O}_{2}$ both cause mitochondrial dysfunction, excessive generation of ROS, and increases in oxidative stress, which lead to disruption of $\left[\mathrm{Ca}^{2+}\right] i$ homeostasis in cells, MPTP opening, and decreases in MMP $[10,13,18]$. In this study, ROS production was increased and ATP levels and MMP were decreased in $\mathrm{A} \beta$ - and $\mathrm{H}_{2} \mathrm{O}_{2}$-exposed cells. ECS significantly reduced the intracellular ROS levels to the same levels as in normal cells. Additionally, ECS significantly improved intracellular ATP levels and MMP in A $\beta$ - and H2O2-exposed cells.

Mitochondria are highly dynamic organelles that undergo continuous fusion and fission [44]. A $\beta$ affects the expression levels of these mitochondrial fusion/fission-related proteins by increasing mitochondrial fission gene expression and reducing mitochondrial fusion gene 


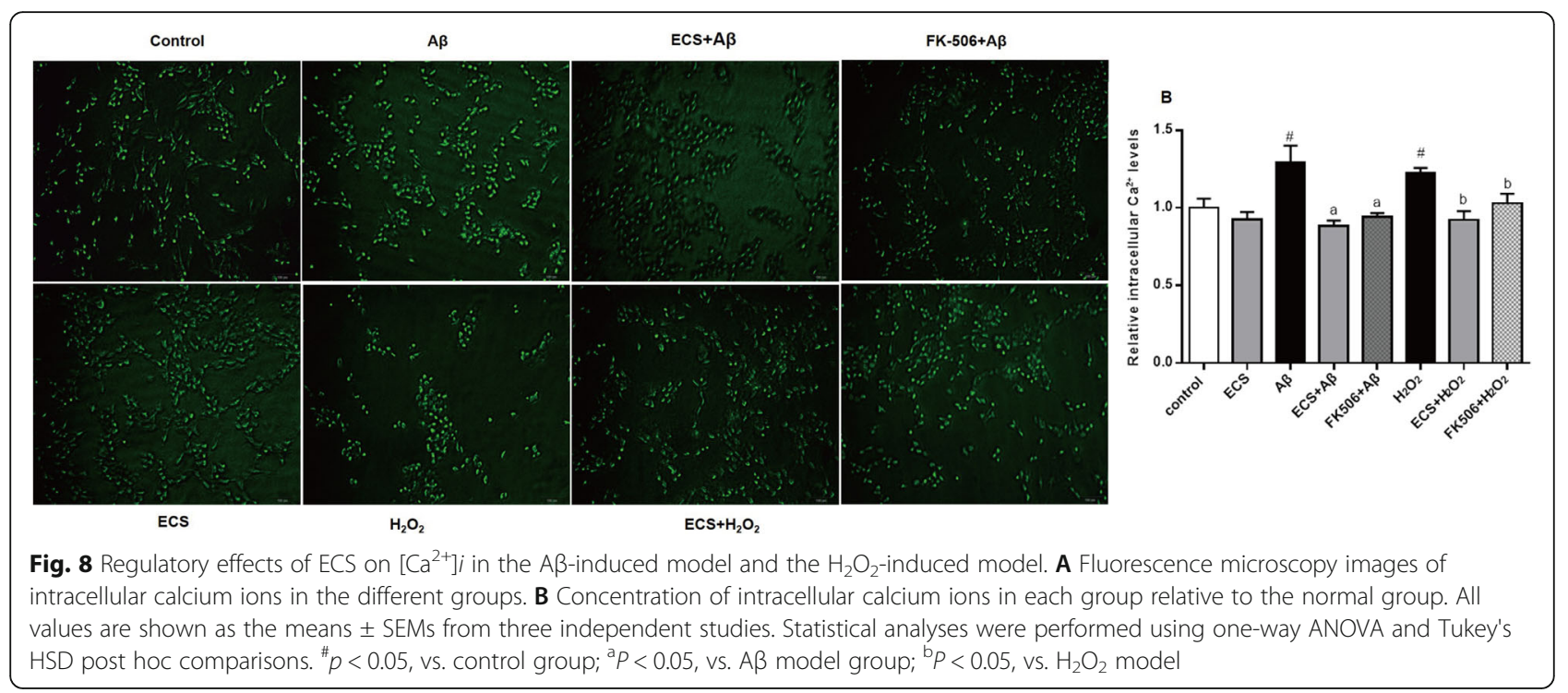

expression [44]. Defects in fission proteins and fusion proteins severely alter mitochondrial morphology and impair mitochondrial function [45]. The mitochondrial fusion proteins Mfn1 and Mfn2 are located in the mitochondrial outer membrane and mainly mediate mitochondrial outer membrane fusion. Mfn2 also plays a crucial role in the conduction of calcium signals [46, 47]. Opa1 is located in the mitochondrial inner membrane and mainly mediates mitochondrial inner membrane fusion, and it also helps maintain the morphology of the mitochondrial cristae [48]. Drp1 and Fis1 are involved in mitochondrial division [47]. Phosphorylation of Drp1 leads to excessive mitochondrial division, which leads to an imbalance in mitochondrial dynamics [21]. In our study, the p-Drp1 (Ser637) expression level in $\mathrm{H}_{2} \mathrm{O}_{2}$-exposed cells showed an increasing trend relative to that in normal cells, but the difference was not significant. ECS intervention significantly decreased the expression of $\mathrm{p}$ Drp1 (Ser637) in both model groups. The p-Drp1/Drp1 ratios in the model groups were decreased significantly, indicating that the phosphorylation levels of Drp1 were increased in the $A \beta$ - and $\mathrm{H}_{2} \mathrm{O}_{2}$-exposed cells. Furthermore, we also found that the expression levels of both Drp1 and p-Drp1 were decreased in the control group treated with ECS, suggesting that the therapeutic targets of ECS may be the receptor molecules of DRP1.

Fis1 is a membrane receptor for Drp1 and is mainly involved in mitochondrial division [22]. Studies have shown that the overexpression of Fis1 and p-Drp1 in mitochondria can inhibit the division and proliferation of mitochondria [22]. Our study results showed that the expression levels of Fis1 were increased significantly in $\mathrm{H}_{2} \mathrm{O}_{2}$-exposed cells compared with normal cells and were also higher than those in A $\beta$-exposed cells. ECS significantly reduced the expression levels of Fis1 in
$\mathrm{H}_{2} \mathrm{O}_{2}$-exposed cells. However, the expression levels of Fis1 in A $\beta$-exposed cells showed a slight increasing trend without a significant difference, similar to the results in another study [49]. Overall, in this study, only the expression levels of Drp1, p-Drp1, and Fis1 changed significantly. The expression of other proteins related to mitochondrial fusion, namely, Opa1, Mfn1, and Mfn2, showed no significant differences. This was contrary to our expectations but was similar to the results of other studies $[49,50]$. These results suggest that the phosphorylation of Drp1 may be an essential factor triggering mitochondrial division and indirectly affect the expression levels of other mitochondrial kinetics-related proteins [51].

Calcium signals affect mitochondrial dynamics by activating calcium-sensitive effectors, such as calcineurin $(\mathrm{CaN})$ [21]. Calcineurin is a serine/threonine protein phosphatase (PPase) with a critical role in signal transduction; for example, it regulates the dephosphorylation of Drp1 at Ser337 [52, 53]. Our results showed that ECS reduced the concentrations of $\mathrm{Ca}^{2+}$ and the expression levels of $\mathrm{CaN}$ in $\mathrm{A} \beta$ - and $\mathrm{H}_{2} \mathrm{O}_{2}$-exposed cells and decreased Drp1 phosphorylation. Thus, ECS can maintain mitochondrial ultrastructure and function in AD models by reducing intracellular calcium ion concentrations, decreasing the expression level of $\mathrm{CaN}$, promoting Drp1 dephosphorylation, and maintaining the balance of mitochondrial dynamics.

There were some limitations in this study. First, the study investigating the effect of ECS on mitochondrial dysfunction was a preliminary in vitro study. Behavioral and pharmacological studies in animals should be considered in the future. Second, the components of ECS that play major roles in the therapeutic effects remain unclear and need further study. 


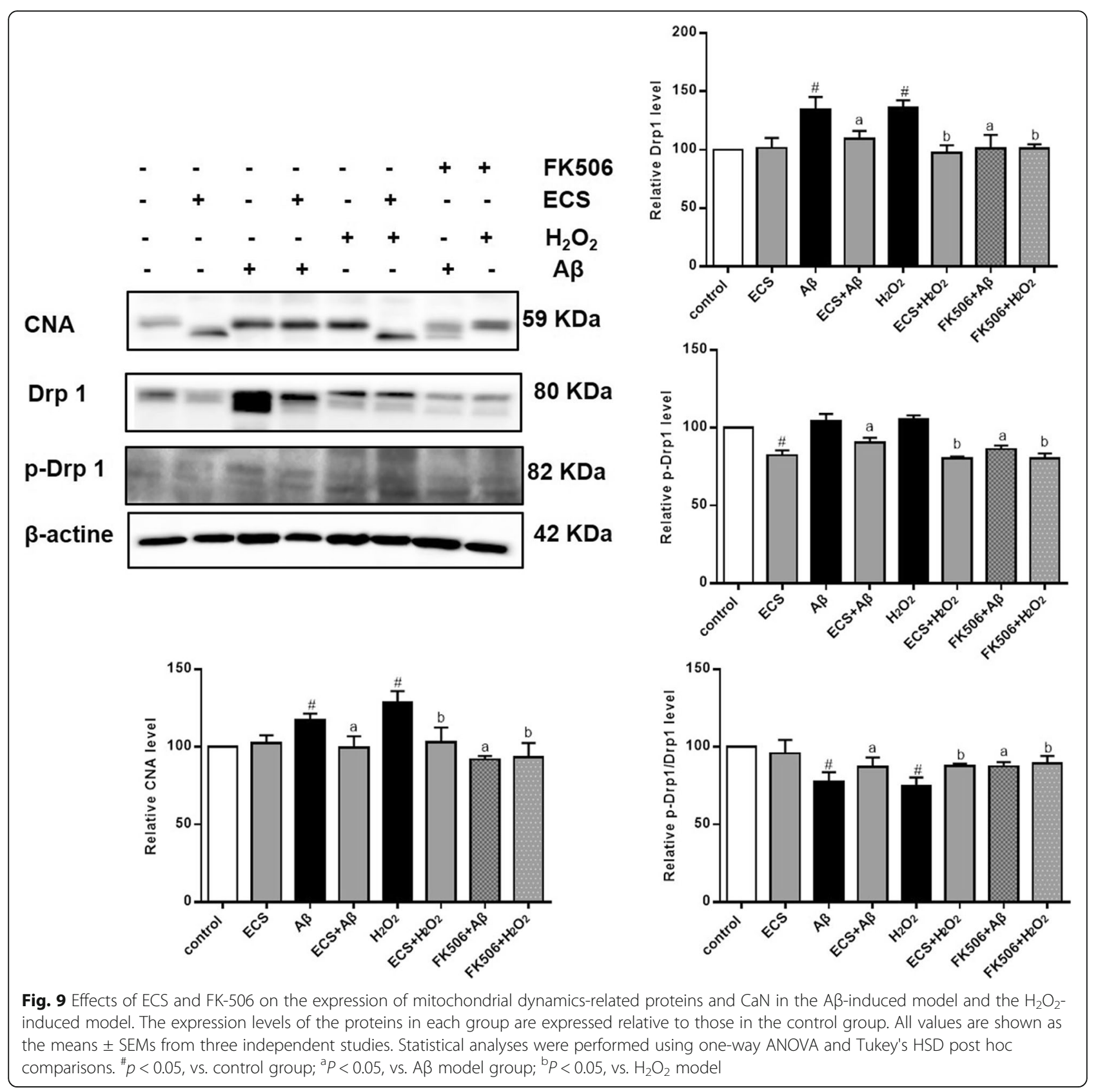

\section{Conclusion}

According to our study results, ECS enhanced MMP, increased intracellular ATP levels, protected mitochondrial ultrastructure and function, and decreased intracellular ROS levels in the $A \beta$ - and $\mathrm{H}_{2} \mathrm{O}_{2}$-induced $\mathrm{AD}$ models in vitro. Additionally, ECS regulated the expression levels of mitochondrial dynamics-related proteins; for example, it reduced the dephosphorylation of Drp1 at Ser637 and reduced the expression of Fis1 in the $\mathrm{H}_{2} \mathrm{O}_{2}$-induced model. Further study was performed to explore the mechanism by which ECS reduced the phosphorylation of Drp1 at Ser637. The results indicated that ECS reduced overload of intracellular calcium ions, decreased the expression levels of $\mathrm{CaN}$, and increased the dephosphorylation of Drp1 in $\mathrm{A} \beta$ - and $\mathrm{H}_{2} \mathrm{O}_{2}$-exposed cells. Therefore, ECS can maintain the balance of mitochondrial dynamics by reducing overload of intracellular calcium ions and increasing dephosphorylation of Drp1 at Ser637, thereby increasing MMP and intracellular ATP levels and maintaining the stability of mitochondrial structure and function in $\mathrm{A} \beta$ - and $\mathrm{H}_{2} \mathrm{O}_{2}$-induced $\mathrm{AD}$ models. Collectively, our findings provide evidence regarding mitochondrial status and successive changes in $\mathrm{AD}$ and suggest a new therapeutic strategy for $\mathrm{AD}$ patients. 


\section{Abbreviations}

AD: Alzheimer's disease; ECS: The extracts of Cynomorium songaricum; MMP: Mitochondrial membrane potential; ROS: Reactive oxygen species; SP: Senile plaques; NFT: Neurofibrillary tangle; APP: Amyloid precursor protein; mtDNA: Mitochondrial DNA; MPTP: Mitochondrial permeability transition pores; Drp1: Dynamin-related protein 1; Fis1: Fission 1;

Mfn1: Mitofusin l; Opa 1: Optic atrophy 1; LOD: Limit of detection; LOQ: Limit of quantitation; DMEM: Dulbecco's modified eagle media; FBS: Fetal bovine serum; $\mathrm{H}_{2} \mathrm{O}_{2}$ : Hydrogen peroxide; CCK-8: Cell Counting Kit-8; PBS: Phosphatebuffered saline; TEM: Transmission electron microscope; SDS-PAGE: Sodium dodecyl sulfate-polyacrylamide gel electrophoresis; PVDF: Polyvinylidene difluoride; TBST: Tris Buffered Saline with Tween 20; DPBS: Dulbecco's phosphate-buffered saline; HPLC: High-performance liquid chromatography; RSD: Relative standard deviation; CaN: Calcineurin

\section{Supplementary Information}

The online version contains supplementary material available at https://doi. org/10.1186/s12906-021-03375-2.

Additional file 1 Fig. S1. Effects of ECS on cell viability of HT22 under different action times and concentrations. Cells were treated with $12.5 \mu \mathrm{g} / \mathrm{mL}, 25 \mu \mathrm{g} / \mathrm{mL}, 50 \mu \mathrm{g} / \mathrm{mL}, 100 \mu \mathrm{g} / \mathrm{mL}, 200 \mu \mathrm{g} / \mathrm{mL}, 400 \mu \mathrm{g} / \mathrm{mL}$, and $800 \mu \mathrm{g} / \mathrm{mL}$ of ECS, respectively. CCK-8 was added after the cells were treated with ECS for 12 and $24 \mathrm{~h}$, and the cell viability was calculated according to the OD value. ${ }^{*} P<0.05$, compared with the control group $(n=$ 6). Fig. S2. Effects of $A \beta$ on the viability of HT22 cells. Different concentration of $A \beta, 10 \mu \mathrm{M}, 20 \mu \mathrm{M}, 40 \mu \mathrm{M}, 80 \mu \mathrm{M}$, respectively acted on the $\mathrm{HT} 22$ cells for $12 \mathrm{~h}$ and $24 \mathrm{~h}$. The cell ability under different concentration and administration time of $A \beta$ was calculated according to the OD value. ${ }^{*} P<0.05$, compared with control group. Fig. S3. Effect of $\mathrm{H}_{2} \mathrm{O}_{2}$ on the viability of $\mathrm{HT}_{2} 2$ cells. Different concentration of $\mathrm{H}_{2} \mathrm{O}_{2}, 50 \mu \mathrm{M}, 100 \mu \mathrm{M}$ $200 \mu \mathrm{M}, 400 \mu \mathrm{M}, 800 \mu \mathrm{M}$, respectively acting on HT22 cells for $2 \mathrm{~h}, 4 \mathrm{~h}, 8$ $\mathrm{h}, 12 \mathrm{~h}$, and $24 \mathrm{~h}$. The cell ability under different concentration and different administration time of $\mathrm{H}_{2} \mathrm{O}_{2}$ was calculated by the $\mathrm{OD}$ value. ${ }^{*} \mathrm{P}<0.05$, compared with control group.

\section{Acknowledgements}

Not applicable.

\section{Authors' contributions}

D.C. and Y.L. designed the studies, D.C. analyzed the data, performed the experiments, wrote and revised the manuscript. X.W., X.J.L., L.S., L.L.L., M.Y.H. performed some of the experiments. Y. L. supervised the project, generated resources, reviewed and finally approved the manuscript.

\section{Funding}

This work was supported by the Natural Science Foundation of Beijing Municipality [grant number: 7182095] and Research Fund of Beijing University of Chinese Medicine [grant number: 3020072120005].

\section{Availability of data and materials}

All data generated or analysed during this study are included in this published article and its ikmentary information files.

\section{Declarations}

\section{Ethics approval and consent to participate}

Not applicable.

\section{Consent for publication}

All the authors have read the manuscript, and consent for publication.

\section{Competing interests}

The authors declare that they have no competing interests.

\section{Author details}

${ }^{1}$ School of Chinese Medicine, Beijing University of Chinese Medicine, Beijing, China. ${ }^{2}$ School of Chinese Medicine, LKS Faculty of Medicine, The University of Hong Kong, Hong Kong, China.
Received: 2 December 2020 Accepted: 6 July 2021

Published online: 09 August 2021

\section{References}

1. Eckert A, Schulz KL, Rhein V, Götz J. Convergence of amyloid-beta and tau pathologies on mitochondria in vivo. Mol Neurobiol. 2010;41(2-3):107-14. https://doi.org/10.1007/s12035-010-8109-5.

2. Coleman PD, Yao PJ. Synaptic slaughter in Alzheimer's disease. Neurobiol Aging. 2003;24(8):1023-7. https://doi.org/10.1016/j.neurobiolaging.2003.09. 001.

3. Salloway S, Sperline R, Fox NC, Blennow K, Klunk W, Raskind M, et al. Two phase 3 trials of bapineuzumab in mild to moderate Alzheirmer's disease. $\mathrm{N}$ Engl J Med. 2014;370(4):322-33. https://doi.org/10.1056/NEJMoa1304839.

4. Morris GP, Clark LA, Vissel B. Inconsistencies and controversies surrounding the amyloid hypothesis of Alzheimer's disease. Acta Neuropathologica Communications. 2014;2:135

5. Swerdlow RH, Burns JM, Khan SM. The Alzheimer's disease mitochondrial cascade hypothesis: progress and perspectives. Biochim Biophys Acta. 2014; 1842:1219-31.

6. Roychaudhuri R, Yang M, Hoshi MM, Teplow DB. Amyloid beta-protein assembly and Alzheimer disease. J Biol Chem. 2009;284(8):4749-53. https:// doi.org/10.1074/jbc.R800036200.

7. Swerdlow RH, Burns JM, Khan SM. The Alzheimer's disease mitochondrial cascade hypothesis. J Alzheimer Dis. 2010;20(Suppl):265-79.

8. Giovanna C, Wolfgang V. Mitochondria as potential targets in Alzheimer disease therapy: An update. Front Pharmacol. 2019;10:902.

9. Pavlov PF, Wiehager B, Sakai J, Frykman S, Behbahani H, Winblad B, et al. Mitochondrial gamma-secretase participates in the metabolism of mitochondria-associated amyloid precursor protein. FASEB J. 2011;25(1):7888. https://doi.org/10.1096/fj.10-157230.

10. Pagani L, Eckert A. Amyloid-Beta interaction with mitochondria. Int J Alzheimers Dis. 2011;925050. https://doi.org/10.4061/2011/925050.

11. Devi L, Ohno M. Mitochondrial dysfunction and accumulation of the betasecretase-cleaved C-terminal fragment of APP in Alzheimer's disease transgenic mice. Neurobiol Dis. 2012;45(1):417-24. https://doi.org/10.1016/j. nbd.2011.09.001.

12. Pinho CM, Teixeira PF, Glaser E. Mitochondrial import and degradation of amyloid-beta peptide. Biochim Biophys Acta. 2014;1837:1069-74.

13. Spuch C, Ortolano S, Navarro C. New insights in the amyloid-Beta interaction with mitochondria. J Aging Res. 2012;324968. https://doi.org/1 $0.1155 / 2012 / 324968$.

14. Lin MT, Beal MF. Mitochondrial dysfunction and oxidative stress in neurodegenerative diseases. Nature. 2006;443:787-95.

15. Chua LM, Lim ML, Wong BS. The Kunitz-protease inhibitor domain in amyloid precursor protein reduces cellular mitochondrial enzymes expression and function. Biochem Biophys Res Commun. 2013;437(4):642-7. https://doi.org/10.1016/j.bbrc.2013.07.022.

16. Sondheimer N, Zollo O, Deerlin W, Trojanowski JQ. Analysis of cerebrospinal fluid mitochondrial DNA levels in Alzheimer disease. Ann Neurol. 2014;75(3): 458-60. https://doi.org/10.1002/ana.24107.

17. Tönniesa E, Trushina E. Oxidative stress, synaptic dysfunction, and Alzheimer's disease. J Alzheimers Dis. 2017;57(4):1105-21. https://doi.org/1 0.3233/JAD-161088.

18. Manczak M, Mao P, Calkins MJ, Cornea A, Reddy AP, Murphy MP, et al. Mitochondria-targeted antioxidants protect against amyloid-beta toxicity in Alzheimer's disease neurons. J Alzheimers Dis. 2010;20(Suppl):609-31.

19. Zhao J, Lendahl U, Nistér M. Regulation of mitochondrial dynamics: convergences and divergences between yeast and vertebrates. Cell Mol Life Sci. 2013;70(6):951-76. https://doi.org/10.1007/s00018-012-1066-6.

20. Manczak M, Calkins MJ, Ressy PH. Impaired mitochondrial dynamics and abnormal interaction of amyloid beta with mitochdrial protein Drp1 in neurons from patients with Alzheimer's disease: implications for neuronal damage. Hum Mol Genet. 2011;20(13):2495-509. https://doi.org/10.1093/ hmg/ddr139.

21. Cereghetti GM, Stangherlin A, de Brito MO, Chang CR, Blackstone C, Bernardi $P$, et al. Dephosphorylation by calcineurin regulates translocation of Drp1 to mitochondria. Proc Natl Acad Sci U S A. 2008;105(41):15803-8. https://doi.org/10.1073/pnas.0808249105.

22. Crack PJ, Taylor JM, Flentjar NJ, de Haan J, Hertzog P, lannello RC, et al. Increased infarct size and exacerbated apoptosis in the glutathione peroxidase-1 (Gpx-1) knockout mouse brain in response to ischemia/ 
reperfusion injury. J Neurochem. 2001;78(6):1389-99. https://doi.org/10.104 6/j.1471-4159.2001.00535.x

23. Du H, Yan SS. Mitochondrial medicine for neurodegenerative diseases. Int J Biochem Cell Biol. 2010;42(5):560-72. https://doi.org/10.1016/j.biocel.2010.01. 004.

24. Cheng D, Zheng JC, Ma SY, Murtaza G, Wahab A, Yu CY, et al. Chemical constituents, and pharmacological and toxicological effects of Cynomorium songaricum: An overview. Trop J Pharm Res. 2017;16:2689-96.

25. Hiroki S. Composition of Kampo complement (1)-the ingredients of Cynomorium. Foreign Med Sci-Section Tradit Chin Med. 1989;11:36-42.

26. Lu Y, Wang QG, Melzig MF, Kristina JS. Extracts of Cynomorium songaricum protect SK-N-SH human neuroblastoma cells against Staurosporine-induced apoptosis potentially through their radical scavenging activity. Phytother Res. 2009;23(2):257-61. https://doi.org/10.1002/ptr.2605.

27. Lu Y, Cheng FF, Wang XQ, Zhong XG, Wang QG. Antioxidant activities of different extracts of Cynomorium Songaricum and their protective effects against hypoxanthine/xanthine oxidase-induced cell injury: a comparative study. J Anhui Tradit Chin Med Coll. 2012;31:57-61.

28. Ma SY, Chang HS, Cheng D, Zheng JC, Tian FZ, Li LL, et al. ERK/MAPKmediated alleviation in cognitive dysfunction in chronically stressed mice treated with ethyl acetate extracts of Cynomorium Songaricum. Bulg Chem Commun. 2017:49:178-83.

29. Tian FZ, Chang HS, Liu JX, Zheng JC, Cheng D, Lu Y. Cynomorium songaricum extract alleviates memory impairment through increasing CREB/ BDNF via suppression of p38MAPK/ERK pathway in ovariectomized rats. Evid Based Complement Alternat Med. 2019;2019:9689325.

30. Cheng D, Chang HS, Wang X, Ma SY, Li LL, Li XJ, et al. Rapid identification and characterization of chemical components in the active part of herba cynomorii by UPLC/LTQ-Orbitrapa MS. World Chinse Med. 2019;14:306-10.

31. Kannel PR, Lee S, Kanel SR, Khan SP. Chemometric application in classification and assessment of monitoring locations of an urban river system. Anal Chim Acta. 2007;582(2):390-9. https://doi.org/10.1016/j.aca.2 006.09.006.

32. Kim HG, Ju MS, Park H, Seo Y. Evaluation of Samjunghwan, a traditional medicine, for neuroprotection against damage by amyloid-beta in rat cortical neurons. J Ethnopharmacol. 2010;130(3):625-30. https://doi.org/10.1 016/j.jep.2010.05.040.

33. An SY, Youn GS, Kim H, Choi SY, Park J. Celastrol suppresses expression of adhesion molecules and chemokines by inhibiting JNK-STAT1/NF-KB activation in poly(l:C)-stimulated astrocytes. BMB Rep. 2017;50(1):25-30. https://doi.org/10.5483/BMBRep.2017.50.1.114.

34. Bass JJ, Wilkinson DJ, Rankin D, Phillips BE, Szewczyk NJ, Smith K, et al. An overview of technical considerations for western blotting applications to physiological research. Scand J Med Sci Sports. 2017;27(1):4-25. https://doi, org/10.1111/sms.12702

35. Lendahl U, McKay RD. The use of cell lines in neurobiology. Trends Neurosci. 1990;13(4):132-7. https://doi.org/10.1016/0166-2236(90)90004-T.

36. Caldwell JD, Shapiro RA, Jirikowski GF, Suleman F. Internalization of sex hormonebinding globulin into neurons and brain cells in vitro and in vivo. Neuroendocrinology. 2007;86(2):84-93. https://doi.org/10.1159/000107072.

37. Gouras GK, Tsai J, Naslund J, Vincent B, Edgar M, Checler F, et al. Intraneuronal Aß42 accumulation in human brain. Am J Pathol. 2000;156(1): 15-20. https://doi.org/10.1016/S0002-9440(10)64700-1.

38. Qu M, Zhou Z, Xu SC, Chen CH, Yu ZP, Wang DG. Mortalin overexpression attenuates beta-amyloid-induced neurotoxicity in SH-SY5Y cells. Brain Res. 2011;1368:336-45. https://doi.org/10.1016/j.brainres.2010.10.068.

39. Swomley AM, Butterfield DA. Oxidative stress in Alzheimer disease and mild cognitive impairment: evidence from human data provided by redox proteomics. Arch Toxicol. 2015;89(10):1669-80. https://doi.org/10.1007/s002 04-015-1556-z.

40. Kühlbrandt W. Structure and function of mitochondrial membrane protein complexes. BMC Biol. 2015;13:89.

41. Wang X, Su B, Lee HG, Li XY, Perry G, Smith MA, et al. (2009). Impaired balance of mitochondrial fission and fusion in Alzheimer's disease. J Neurosci. 2009; 29(28):9090-103. https://doi.org/10.1523/JNEUROSCl.1357-09.2009.

42. Yu T, Robotham JL, Yoon Y. Increased production of reactive oxygen species in hyperglycemic conditions requires dynamic change of mitochondrial morphology. Proc Natl Acad Sci U S A. 2006;103(8):2653-8. https://doi.org/10.1073/pnas.0511154103.

43. Meeusen S, DeVay R, Block J, Cassidy-Stone A, Wayson S, McCaffery JM, et al. Mitochondrial inner-membrane fusion and crista maintenance requires the dynamin-related GTPase Mgm1. Cell. 2006;127(2):383-95. https://doi. org/10.1016/j.cell.2006.09.021.

44. Zhu X, Perry G, Smith MA, Wang XL. Mitochondrial dynamics in the pathogenesis of Alzheimer's disease. J Alzheimers Dis. 2013;33:S253-62.

45. Chen $\mathrm{H}$, Chan DC. Mitochondrial dynamics in mammals. Curr Top Dev Biol. 2004:59:119-44. https://doi.org/10.1016/50070-2153(04)59005-1.

46. Wang W, Xie Q, Zhou X, Zhou X, Yao J, Zhu X, et al. Mitofusin-2 triggers mitochondria $\mathrm{Ca}^{2+}$ influx from the endoplasmic reticulum to induce apoptosis in hepatocellular carcinoma cells. Cancer Lett. 2015;358:47-58.

47. Itoh K, Nakamura K, lijima M, Sesaki H. Mitochondrial dynamics in neurodegeneration. Trends Cell Biol. 2013;23(2):64-71. https://doi.org/10.101 6/j.tcb.2012.10.006

48. Pernas L, Scorrano L. Mito-Morphosis: mitochondrial fusion, fission, and cristae remodeling as key mediators of cellular function. Annu Rev Physiol. 2016:78:505-31.

49. Kang S, Byun J, Son SM, Mook-Jung I. Thrombospondin-1 protects against A -induced mitochondrial fragmentation and dysfunction in hippocampal cells. Cell Death Discovery. 2018;4(1):31-43. https://doi.org/10.1038/s41420017-0023-4.

50. Lee DG, Min JS, Lee HS, Lee DS. Isoliquiritigenin attenuates glutamateinduced mitochondrial fission via calcineurin-mediated Drp1 dephosphorylation in HT22 hippocampal neuron cells. Neuro Toxicol. 2018; 68:133-41.

51. Qi X, Disatnik MH, Shen N, Sobel R, Mochly-Rosen. Aberrant mitochondrial fission in neurons induced by protein kinase $\mathrm{C}\{$ delta\} under oxidative stress conditions in vivo. Mol Biol Cell. 2011;22:256-65.

52. Klee CB, Crouch TH, Krinks MH. Calcineurin: a calcium- and calmodulinbinding protein of the nervous system. Proc Natl Acad Sci U S A. 1979; 76(12):6270-3. https://doi.org/10.1073/pnas.76.12.6270.

53. Slupe AM, Merrill RA, Flippo KH, Lobas MA, Houtman JCD, Strack S. A calcineurin docking motif (LXVP) in dynamin-related protein 1 contributes to mitochondrial fragmentation and ischemic neuronal injury. J Biol Chem. 2013;288(17):12353-65. https://doi.org/10.1074/jbc.M113.459677.

\section{Publisher's Note}

Springer Nature remains neutral with regard to jurisdictional claims in published maps and institutional affiliations.

Ready to submit your research? Choose BMC and benefit from:

- fast, convenient online submission

- thorough peer review by experienced researchers in your field

- rapid publication on acceptance

- support for research data, including large and complex data types

- gold Open Access which fosters wider collaboration and increased citations

- maximum visibility for your research: over $100 \mathrm{M}$ website views per year

At $\mathrm{BMC}$, research is always in progress.

Learn more biomedcentral.com/submission 